\title{
Cytological Diagnosis of Hashimoto's Thyroiditis Revealing the Increased Frequency than Expected: A Retrospective Study of 750 Thyroid Aspirates
}

\author{
Faiyaz Ahmad ${ }^{1}$, Ashutosh Kumar ${ }^{2}$, Jyotsana Khatri ${ }^{3}$, Ankita Mittal' ${ }^{1}$, Seema Awasthi ${ }^{4}$, Shyamoli Dutta ${ }^{4}$ \\ ${ }^{1}$ Assistant Professor, ${ }^{2}$ Associate Professor, ${ }^{3}$ Post Graduate Student, ${ }^{4}$ Professor, \\ Department of Pathology, Teerthanker Mahaveer Medical College and Research Centre, Moradabad, Uttar Pradesh, India.
}

\begin{abstract}
Background: Hashimoto's thyroiditis (HT), an autoimmune disease is the commonest cause of hypothyroidism in iodine sufficient areas of the world. Fine needle aspiration cytology (FNAC) is the gold standard for the diagnosis of this condition.

Aims: To assess the frequency of HT in total number of thyroid aspirates on the basis of cytomorphology and correlate it with clinical history, radiological findings, thyroid hormone status and antithyroid antibody titres wherever available.

Material and methods: At a tertiary level teaching hospital in north India we retrospectively analysed 750 thyroid aspirates and found $58 \mathrm{HT}$ in these on cytomorphology. Clinical findings, thyroid function and thyroid peroxidise (TPO) antibody profile were correlated with cytomorphological features. We further subdivided it in different age and sex groups to assess the frequency in all these groups.

Results: Fine needle aspiration smears were satisfactory for evaluation in all cases with $\mathrm{HT}$. frequency of $\mathrm{HT}$ was more than expected, $58(7.73 \%)$ out of total 750 aspirates. Most patients with HT were women $50(86.21 \%)$ and in $2^{\text {nd }}$ to $3^{\text {rd }}$ decades. Diffuse goitre was the commonest $41(70.69 \%)$ presentation. Hypothyroidism was the commonest $35(60.34 \%)$ feature. Anti TPO antibodies were elevated in 10/12 (83.33\%) patients.
\end{abstract}

\section{INTRODUCTION}

In 1912, Hakaru Hashimoto was first to describe a chronic disorder of thyroid gland and called it as strauma lymphomatosa, which bears his name Hashimoto's thyroiditis (HT) later. ${ }^{1} \mathrm{HT}$ may usually be considered a synonym of chronic lymphocytic thyroiditis or autoimmunethyroiditis. ${ }^{2}$ It has a prevalence rate of $1-4 \%$ and incidence of $3-6 / 10,000$ population per year, the second most common lesion of thyroid diagnosed by cytology, next to endemic goitre., This is an autoimmune disorder affecting women more commonly than men. Diffuse thyroid enlargement is the usual presenting feature, but asymmetry may occur with localized nodular enlargement. ${ }^{4}$ It may be associated with hypothyroidism, euthyroidism or occasionally transient hyperthyroidism but ultimately hypothyroidism develops gradually. ${ }^{3}$

Fine needle aspiration cytology (FNAC) is highly sensitive in diagnosing HT, with a diagnostic accuracy rate of $92 \% .{ }^{4}$ The diagnosis of HT on FNAC smears is made by finding the oxyphilic transformation of epithelial cells (Hurthle cells), infiltration of follicles by lymphocytes and plasma cells, presence of moderate number of it in background with scanty or absence of colloid. ${ }^{5}$

To diagnose HT FNAC is considered superior as well as more cost-effective than antibody screening. ${ }^{5-7}$ However, there are certain pitfalls of FNAC in diagnosing $\mathrm{HT}$, it may be missed in smears showing abundant colloid or cytologic evidence of
Classical HT was seen in $40(69 \%)$ and florid lymphocytic thyroiditis pattern in $18(31 \%)$ patients.

Conclusion: Hashimoto's thyroiditis is more frequent than expected, especially in women of younger age groups.

Keywords: Fine needle aspiration cytology, Hashimoto's thyroiditis, Thyroid.

\section{*Correspondence to:}

Dr. Faiyaz Ahmad, Assistant Professor, Department of Pathology, TMMC \& RC, Moradabad, UP, India.

E-mail: dr.faiyaz146@gmail.com

\section{Article History:}

Received: 02-05-2016, Revised: 12-05-2016, Accepted: 25-05-2016

\begin{tabular}{|l|c|}
\hline \multicolumn{2}{|c|}{ Access this article online } \\
\hline $\begin{array}{l}\text { Website: } \\
\text { www.jmrp.com }\end{array}$ & \\
\hline Dol: & \\
10.21276/ijmrp.2016.2.3.031 & \\
\hline
\end{tabular}

hyperplasia. ${ }^{3}$ Lymphocytic infiltration of the gland in Grave's disease, marked Hurthle cell change with sparse inflammatory cells mimicking Hurthle cell neoplasm and lymphoma in older patients may result in an overlap of cytological appearances with HT. ${ }^{5}$

We observed that there was more frequent diagnosis of $\mathrm{HT}$ on cytology than expected by earlier data. This prompted us to undertake this study to assess if there was any rise in frequency of $\mathrm{HT}$ in this region by adhering the strict cytomorphological criteria for diagnosis and correlating it with clinical history, radiological findings, thyroid hormone status and antithyroid antibodies profile wherever available.

\section{MATERIAL AND METHODS}

Patients with thyroid swellings were referred to department of pathology for FNAC during May 2008 - April 2016. A proper written consent was obtained from each patient. Aspiration/nonaspiration technique was used. FNA was done with standard technique using aseptic precautions, $10 \mathrm{cc} / 20 \mathrm{cc}$ disposable syringe and 23 gauge needle. Two to four rapid passes were given. Air-dried smears were stained with May-Grunwald-Giemsa stain and wet ethanol fixed smears were stained with Papanicolaou stain and hematoxylene \& eosine stains. Cases in 
which, smears were unsatisfactory, a repeat aspiration was done. The diagnosis of HT on FNAC was based on finding lymphocytic infiltrates in clusters of follicular epithelial cells, Hurthle cell changes, anisonucleosis, increased number of lymphocytes in the background with or without lymphoid follicles, multinucleated giant cells and scanty or absence of colloid. ${ }^{1,5}$ Hurthle cells are large cells forming small syncytial aggregates, having well defined abundant finely granular eosinophilic cytoplasm, nuclei larger than normal and much more variable in size.5,9

Data was collected age, gender, diffuse/nodular enlargement of thyroid, radiological findings, thyroid function, antithyroid antibodies, family history of $\mathrm{HT}$ and other autoimmune diseases and analyzed in correlation with cytomorphological findings.

Table 1: Age and sex distribution of 58 patients with Hashimotos thyroiditis

\begin{tabular}{lccc}
\hline Age groups (years) & Male & Female & Total \\
\hline $\mathbf{1 0}-\mathbf{2 0}$ & 4 & 17 & 21 \\
$\mathbf{2 1}-\mathbf{3 0}$ & 0 & 18 & 18 \\
$\mathbf{3 1}-\mathbf{4 0}$ & 1 & 8 & 9 \\
$\mathbf{4 1}-\mathbf{5 0}$ & 1 & 5 & 6 \\
$\mathbf{5 1}-\mathbf{6 0}$ & 1 & 2 & 3 \\
$\mathbf{6 1}-\mathbf{7 0}$ & 1 & 0 & 1 \\
\hline
\end{tabular}

Table 2: Clinical and laboratory findings in patients with Hashimotos thyroiditis

\begin{tabular}{ll}
\hline Frequency & $\mathbf{7 . 7 3 \%}$ \\
\hline Female : Male & $6.25: 1$ \\
Nodular presentation & $13.70 \%$ \\
Most common age group & $2^{\text {nd }}-3^{\text {rd }}$ decades \\
Thyroid function & Available in 51 patients $(87.93 \%)$ \\
Hypothyroid & $22(37.93 \%)$ \\
Euthyroid & $35(60.34 \%)$ \\
Hyperthyroid & $1(1.72 \%)$ \\
Antithyroid antibodies & Available in 12 patients $(20.69 \%)$ \\
Elevated anti TPO & $10(83.33 \%)$ \\
antibodies & \\
\hline
\end{tabular}

Table 3: Frequency of cytomorphological features in patients with Hashimotos thyroiditis

\begin{tabular}{lc}
\hline Cytomorphological featutures & Number of patients \\
\hline Increased background lymphoid & 58 \\
cells & \\
Lymphocytic infiltration of follicles & 45 \\
Hurthle cell changes & 42 \\
Anisokaryosis & 52 \\
Giant cells & 7 \\
Presence of colloid & 4 \\
Plasma cells & 4 \\
Histiocytes & 3 \\
Eosinophils & 2 \\
\hline
\end{tabular}

\section{RESULTS}

We included 750 thyroid aspirates, $603(80.40 \%)$ were females and $147(19.60 \%)$ were males with F:M ratio 4.10:1. All the patients aspirated, had a history of goitre.
Out of these 750 thyroid aspirates $58(7.73 \%)$ were diagnosed as $\mathrm{HT}, 50(86.21 \%)$ females and $8(13.78 \%)$ males with F:M ratio $6.25: 1$ (Table-2).their age ranged from 10 to 60 years (mean age female, 35 years and males 38 years) with majority in $2^{\text {nd }}$ to $3^{\text {rd }}$ decades of life (Table-1).

On examination at the time of FNAC 41 (70.69\%) had diffuse goitre, $16(27.59 \%)$ had uneven enlargement of thyroid and 1 $(1.72 \%)$ had solitary nodule. Thyroid hormone evaluation was done in 51 (87.93\%) patients, which revealed 22 (37.93\%) hypothyroid, $35(60.34 \%)$ euthyroid or had subclinical disease and $1(1.72 \%)$ hyperthyroid. The serum TPO antibody titre were determined in $12(20.69 \%)$ patients, values were elevated in 10 $(83.33 \%)$ and normal in $2(16.67 \%)$. Ultrasonography (USG) was done in 40 patients showed diffusely enlarged thyroid with heterogenous echotexture in $25(62.50 \%)$ and micronodules in 12 $(30 \%)$, dominant nodule in $2(5 \%)$ and echogenic septation in 10 (25\%).

FNAC was performed from multiple sites. (Table-3) shows the frequency of cytomorphological features. Increased background lymphoid cells on smear was observed in all 58 cases (Fig-1), lymphocytic infiltration of follicular epithelial cells in 45 (Fig-2), Hurthle cell changes in 42 (Fig-3), plasma cells 4, histiocytes 3 (Fig-4) and colloid was present in only 4 cases.

\section{DISCUSSION}

Hashimoto's thyroiditis is an autoimmune chronic inflammatory disease of the thyroid gland. ${ }^{9}$ It involves lymphocytic infiltration of thyroid gland which is reactive to thyroid antigens. Activated B lymphocytes secrete autoantibodies and cytotoxic T-lymphocytes are largely responsible for destruction of thyroid follicles. Gradually in course of disease the thyroid parenchyma is totally destroyed and replaced by fibrosis. During active phase of destruction there are transient clinical manifestations of thyrotoxicosis due to rapid release of hormones, but ultimately as the gland parenchyma is being replaced by inactive cells and fibrosis the subclinical and overt hypothyroidism ensues.

The incidence of Hashimoto's thyroiditis seems to be increasing in the recent times. In a study conducted by Marwaha RK et al, among 764 goitrous girls 10 to 18 years age from different states of India, $5.6 \%$ of them have diagnosed to have HT on the basis of FNAC. ${ }^{10} \mathrm{~A}$ study conducted by Benvenga et al, concluded that HT has become 10 times more common than it was until the early 1990. ${ }^{11}$ Another study by Zois et al, among school children has shown a three times increase in the incidence of autoimmune thyroiditis compared to a similar survey done 7 years earlier. ${ }^{12}$ In the present study we included 750 successful thyroid aspirates out of which 58 were diagnosed as ht on cytomorphology, which is quite higher than the earlier documented prevalence of $1-4 \%{ }^{3}$ Marwaha RK et al, conducted their study on girls of 10 to 18 years and found $5.6 \% \mathrm{HT}$ among them, in recent study 73 goitrous thyroid were aspirated in this age group and ht was found in 14 $(19.18 \%)$. lodine induced thyroiditis has been well documented in animals, ${ }^{13}$ whereas in humans the prevalence of autoimmune thyroiditis is correlated with high iodine intake. ${ }^{14}$ Many studies reported increase in prevalence of elevated serum antithyroid antibodies titre and lymphocytic infiltration on cytology and histopathology after introduction of iodine prophylaxis. ${ }^{15-20}$ Across the world, with advent of iodization, autoimmune thyroid disease has become the most common cause of hypothyroidism. ${ }^{21}$ 


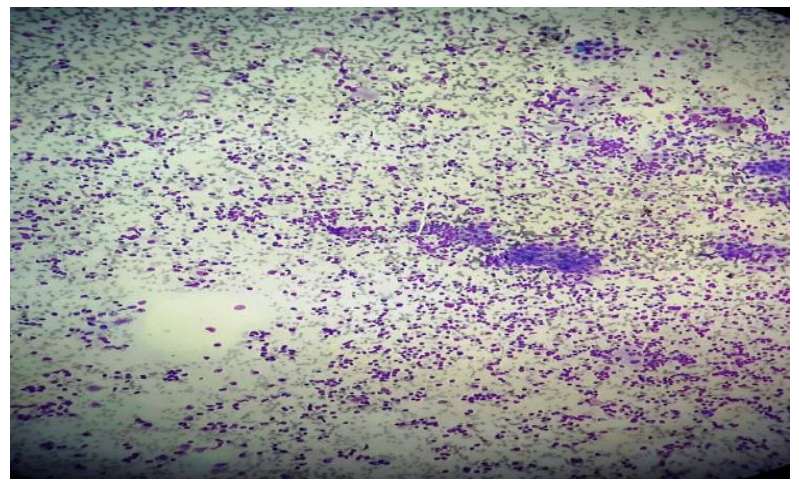

Fig 1: Hurthle cells with increased background lymphocytes (May-Grunwald-Giemsa stain, x100)

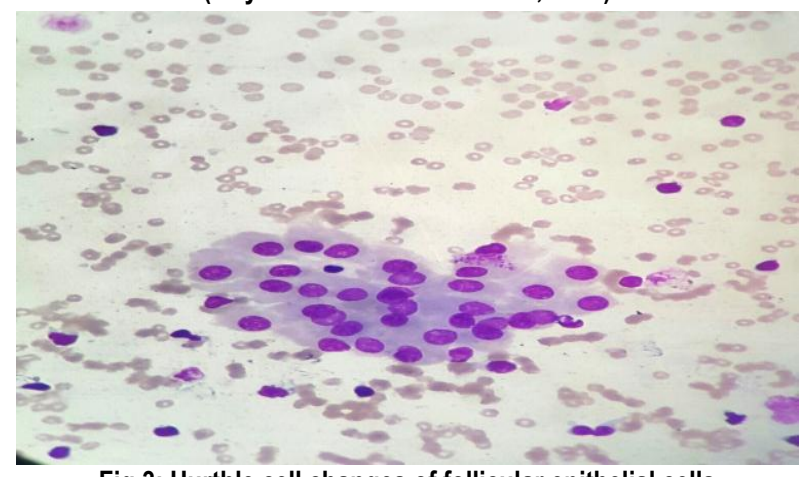

Fig 3: Hurthle cell changes of follicular epithelial cells (May-Grunwald-Giemsa stain, $\mathbf{x} 400$ )

The diagnosis of HT is important because the patient can become hypothyroid and will need lifelong thyroxine supplementation. The prevalence of hypothyroidism in India is higher $(11 \%)$ in comparison to UK (2\%) and USA (4.6\%). ${ }^{21}$ There is also an increased risk of extranodal marginal B-cell lymphoma in patients with HT. The frequency of carcinoma in patients with HT varies between 0.5 and $23.7 \%{ }^{4}$ This emphasises the need for diagnosing HT so that the patients can be on long term follow up. In the present study, out of 52 patients, maximum $(n=39)$ were in $2^{\text {nd }}$ and $3^{\text {rd }}$ decades (Table-1). This is in contrast to the study by Vanderpump et al, in which patients were mainly older women with a mean age at diagnosis being 59 years. ${ }^{22}$ According to Bhatia et al, majority of patients were in $3^{\text {rd }}$ and $4^{\text {th }}$ decades. ${ }^{1}$ This disparity may be due to the occurrence of $\mathrm{HT}$ in young patients in iodine sufficient areas such as ours. This is similar and supported by a study conducted by Chandanwale SS et al, in which most affected patient with ht were in $2^{\text {nd }}, 3^{\text {rd }}$ and $4^{\text {th }}$ decades. ${ }^{23}$

Most patient had diffuse enlargement of thyroid $(n=41)$, uneven enlargement was present in only 16 patient with one had solitary nodule. According to previous reports on HT, nodular presentation was seen in about one third of cases (33\%). Transformation from diffuse to nodular goitre may be due to the process of regeneration and retrogression.

Maximum number of patients were euthyroid $35(60.34 \%)$ in our study it is understandable due to most patients were of younger age group and early stage of disease at the time of diagnosis. Raised levels of TSH with normal T3 \& T4 indicates subclinical hypothyroidism and represents evolutional phase of the disease. Hyphothyroid including subclinical forms were 22 (37.93\%) in our study. Transient hyperthyroid state of HT is due to acute aggravation of thyroid autoimmunity induced destruction of thyroid follicles called as Hashitoxicosis, ${ }^{24}$ found in only one case in our study.

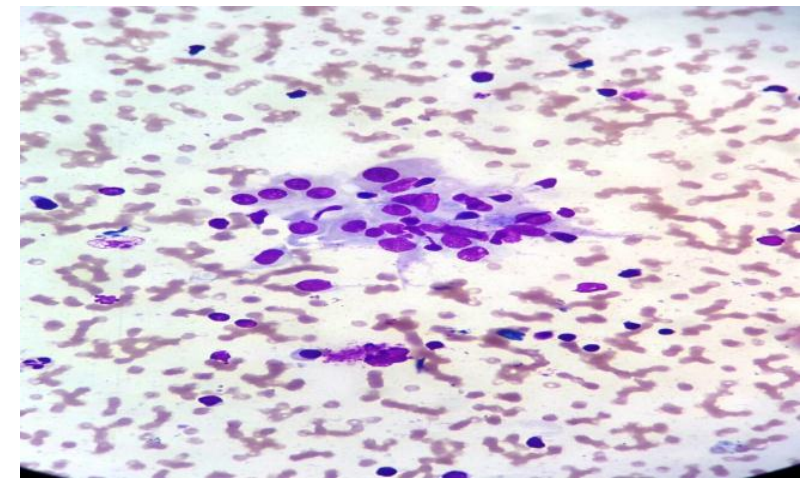

Fig 2: Lymphocytic infiltration in follicular epithelial cells (May-Grunwald-Giemsa stain, $\mathbf{x} 400$ )

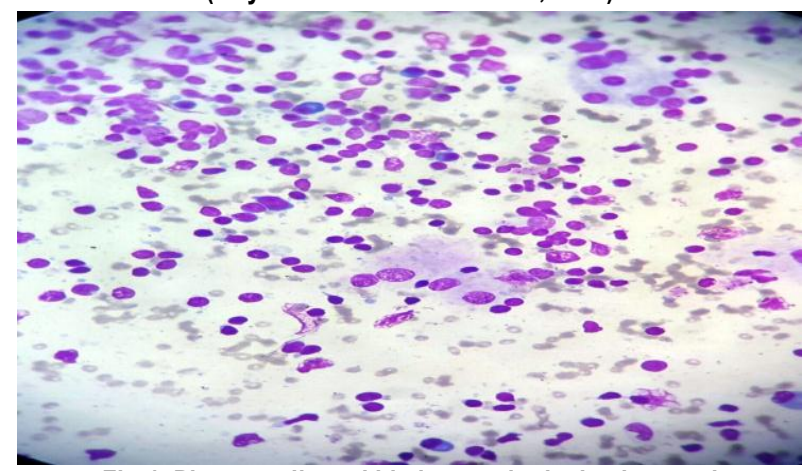

Fig 4: Plasma cells and histiocytes in the background (May-Grunwald-Giemsa stain, x400)

Antithyroid antibody estimation was done only in 12 (20.69\%) patients and serum TPO antibody titres were elevated in 10/12 $(83.33 \%)$ patients. Previous studies reported raised titres in up to $95 \%$ of the patients. ${ }^{25}$ About $20 \%$ adult females without any clinical disease have detectable TPO/Tg antibodies, raising suspicion in its diagnostic value. With proper clinical examination and presentation, the diagnosis of HT may be considered on cytology alone even if antibody titres are negative. ${ }^{3}$

\section{There are two pattern of HT in cytology}

1. Classical HT: seen mostly in older patients, usually hypothyroid, cytology smears shows increased background lymphocytes, infiltration of follicular epithelial cells with or without Hurthle cell changes and colloid remains scanty or absent.

2. Florid lymphocytic thyroiditis: seen mostly in young patients, shows mixed population of numerous lymphoid cells as in reactive lyphadenopathy, epithelioid cells may be scanty. ${ }^{5,26}$ In our study classic HT was seen in $40(69 \%)$ patients and florid lymphocytic thyroiditis was seen in $18(31 \%)$ patients, out of which 13 patients were in $2^{\text {nd }}$ decade, 4 patients in $3^{\text {rd }}$ decade and only one in $5^{\text {th }}$ decade of life. This is explainable on the basis of most patients with $\mathrm{HT}$ in our study are of $2^{\text {nd }}$ and $3^{\text {rd }}$ decade of age group and occurrence of florid lymphocytic pattern in younger individuals, and close to the study by Chandanwale SS et al. ${ }^{23}$

Despite superiority of FNAC in diagnosing HT, have some diagnostic pitfalls. De Quervain's thyroiditis can be a close differential diagnosis on cytomorphology which can be differentiated with mixed inflammatory cell reaction, epithelioid cells, large multinucleated giant cells and degenerating follicular cells on dirty background.

Distinction of autoimmune thyroiditis from lymphoma can be difficult at times specially in adults and elderly. The help can be from age of patient as florid lymphocytic pattern which is closest to 
the lymphoma is common in young patients and lymphoma in adults and elderly. Flow cytometry to demonstrate the monoclonality may be needed for confirmation of diagnosis.

Studies suggest frequency of carcinoma in patients with HT between 0.5 - 23.7\%. ${ }^{4}$ Lymphoma of thyroid arises in the background of HT. In our study there was no associated malignancy, reason can be explained with the fact that most of our patients were in the younger age group at the time of diagnosis and no significant long term follow-up was available.

\section{CONCLUSION}

We report here the increased frequency of HT in different age groups on the basis of cytomorphological study which is gold standard for diagnosing HT, also correlated with clinical history, radiological findings, thyroid hormone status and antithyroid antibody titres wherever available. We also found that HT 6 to 7 times more frequent in females than in males and unexpectedly large number of individuals are of younger age group and mostly females. HT is the most common cause of hypothyroidism in nonendemic areas. Untreated or inadequately treated hypothyroidism in pregnant women can compromise foetal neurocognitive development. So, early diagnosis and treatment will prevent irreversible mental retardation in a large number of newborns.

\section{REFERENCES}

1. Bhatia A, Rajwanshi A, Dash RJ, Mittal BR, Saxena AK. Lymphocytic thyroiditis: Is cytological grading significant? A correlation of grades with clinical, biochemical, ultrasonographic and radionuclide parameters. Cytojournal 2007;4:10.

2. Amino N, Tada H, Hidaka Y. Chronic (Hashimoto's) thyroiditis. In: DeGroot LJ, Jameson JL, editors. Endocrinology. 4 th ed., Vol. 2. Philadelphia: Saunders Publication; 2001. p. 1471-80

3. Kumar N, Ray C, Jain S. Aspiration cytology of Hashimoto's thyroiditis in an endemic area. Cytopathology 2002;13:31-9.

4. Kocjan G. Lymphoid infiltrates. 1 st ed. Fine needle aspiration cytology-diagnostic principles and dilemmas. In: Schroder G, editor. Germany: Springer; 2006. p. 99-101.

5. Orell SR, Sterrett GF, Darell W. Thyroid. In: Orell SR, Sterrett GF, Darell W, editors. Fine needle aspiration cytology. 4 th ed. India: Elsevier Science Ltd; 2005. p. 136-8.

6. Jayaram G, Marwaha RK, Gupta RK, Sharma SK. Cytomorphological aspects of thyroiditis: A study of 51 cases with functional, immunologic and ultrasonographic data. Acta Cytol 1987;31:687-93.

7. Poropatich C, Marcus D, Oertel YC. Hashimoto's thyroiditis: Fineneedle aspirations of 50 asymptomatic cases. Diagn Cytopathol 1994;11:141-5.

8. Cannon J. The Significance of Hürthle Cells in Thyroid Disease. Oncologist. 2011 Oct; 16:1380-7.

9. Thompson LD. Nonneoplastic lesions of the thyroid gland. In: Thompson LD, Goldblum JR, editors. Endocrine pathology. 1 st ed. USA: Elsevier Science Ltd; 2006. p. 20-2

10. Marwaha RK, Tandon N, Karak AK, Gupta N, Verma K, Kochupillai N. Hashimoto's thyroiditis: Countrywide screening of goitrous healthy young girls in postiodization phase in India. J Clin Endocrinol Metab 2000;85:3798-802.

11. Benvenga S, Trimarchi F. Changed presentation of Hashimoto's thyroiditis in North-Eastern Sicily and Calabria (Southern Italy) based on a 31-year experience. Thyroid 2008;18:429-41

12. Zois C, Stavrou I, Kalogera C, Svarna E, Dimoliatis I, Seferiadis K, et al. High prevalence of autoimmune thyroiditis in school children after elimination of iodine deficiency in northwestern Greece. Thyroid 2003;13:485-9.

13. Sundick R, Bagchi N, Brown TR. 1992 The role of iodine in thyroid autoimmunity from chickens to humans: a review. Autoimmunity. 13:61-68.

14. Dayan CM, Daniels GH. 1996 Chronic autoimmune thyroiditis. N Engl J Med. 335:99-107

15. Harach HR, Escalante DA, Onativia A, Outes JL, Day ES, Williams ED. 1985 Thyroid carcinoma and thyroiditis in endemic goiter region before and after iodine prophylaxis. Acta. Endocrinol (Copenh). 108:55-60

16. Oechslin E, Hedinger C. 1985 Hashimoto's lymphomatous thyroiditis and endemic struma. Schweiz Med Wochenschr. 115:1182-1191.

17. Boukis MA, Koutras DA, Souvatzoglou A, Evangelopoulou A, Vrontakis M, Moulopoulos SD. 1983 Thyroid hormone and immunological studies in endemic goiter. J Clin Endocrinol Metab. 57:859-862.

18. Kahaly GJ, Dienes HP, Beyen J, Hommel G. 1998 lodide induces thyroid autoimmunity in patients with endemic goiter: a randomised double blind placebo-controlled trial. Eur J Endocrinol. 139:290-297.

19. Weaver DK, Nishiyama RH, Batsaki JG. lodine induced thyroid disease. Ann Clin Lab Sci 1976;6:545-50.

20. Li Y, Teng D, Shan Z, Teng X, Guan H, Yu X, et al. antithyroperoxidase and antithyroglobulin antibodies in a five-year follow-up survey of populations with different iodine intakes. J Clin Endocrinol Metab 2008;93:1751-7.

21. www.thelancet.com/diabetes-endocrinology vol.2 October 2014 Hypothyroidism in India : more to be done.

22. Vanderpump MP, Tunbridge WM, French JM, Appleton D, Bates $D, C l a r k F$, et al. The incidence of thyroid disorders in the community: A twenty-year follow-up of the Whickham Survey. Clin Endocrinol (Oxf) 1995;43:55-68.

23. Chandanwale SS, Gore CR, Bamanikar SA, Gupta N, Gupta K. Cytomorphologic spectrum of Hashimoto's thyroiditis and its clinical correlation: A retrospective study of 52 patients. CytoJournal 2014;11:9

24. Unnikrishnan AG. Hashitoxicosis: A clinical perspective. Thyroid Res Pract 2013;10:5-6.

25. Amino N, Hagen SR, Yamada N, Refetoff S. Measurement of circulating thyroid microsomal antibodies by the tanned red cell haemagglutination technique: Its usefulness in the diagnosis of autoimmune thyroid diseases. Clin Endocrinol (Oxf) 1976;5:115-25.

26. Poropatich C, Marcus D, Oertel YC. Hashimoto's thyroiditis: Fineneedle aspirations of 50 asymptomatic cases. Diagn Cytopathol 1994;11:141-5.

\section{Source of Support: Nil.}

Conflict of Interest: None Declared.

Copyright: (c) the author(s) and publisher. IJMRP is an official publication of Ibn Sina Academy of Medieval Medicine \& Sciences, registered in 2001 under Indian Trusts Act, 1882.

This is an open access article distributed under the terms of the Creative Commons Attribution Non-commercial License, which permits unrestricted non-commercial use, distribution, and reproduction in any medium, provided the original work is properly cited.

Cite this article as: Faiyaz Ahmad, Ashutosh Kumar, Jyotsana Khatri, Ankita Mittal, Seema Awasthi, Shyamoli Dutta. Cytological Diagnosis of Hashimoto's Thyroiditis Revealing the Increased Frequency than Expected: A Retrospective Study of 750 Thyroid Aspirates. Int J Med Res Prof. 2016; 2(3):143-46. 